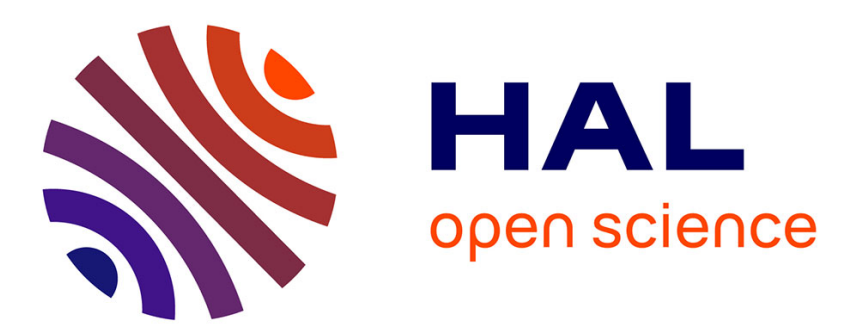

\title{
Occurrence of brominated disinfection byproducts in the air and water of chlorinated seawater swimming pools
}

\author{
Tarek Manasfi, Brice Temime-Roussel, Bruno Coulomb, Laurent Vassalo,
} Jean-Luc Boudenne

\section{- To cite this version:}

Tarek Manasfi, Brice Temime-Roussel, Bruno Coulomb, Laurent Vassalo, Jean-Luc Boudenne. Occurrence of brominated disinfection byproducts in the air and water of chlorinated seawater swimming pools. International Journal of Hygiene and Environmental Health, 2017, 220 (3), pp.583 - 590. 10.1016/j.ijheh.2017.01.008 . hal-01683113

\section{HAL Id: hal-01683113 \\ https://hal.science/hal-01683113}

Submitted on 30 Apr 2018

HAL is a multi-disciplinary open access archive for the deposit and dissemination of scientific research documents, whether they are published or not. The documents may come from teaching and research institutions in France or abroad, or from public or private research centers.
L'archive ouverte pluridisciplinaire HAL, est destinée au dépôt et à la diffusion de documents scientifiques de niveau recherche, publiés ou non, émanant des établissements d'enseignement et de recherche français ou étrangers, des laboratoires publics ou privés. 


\title{
Occurrence of brominated disinfection byproducts in the air and water of chlorinated seawater swimming pools
}

\author{
Tarek Manasfi $^{\mathrm{a} *}$, Brice Temime-Roussel ${ }^{\mathrm{a}}$, Bruno Coulomb $^{\mathrm{a}}$, Laurent Vassalo ${ }^{\mathrm{a}}$, Jean-Luc Boudenne ${ }^{\mathrm{a}}$ \\ ${ }^{a}$ Aix Marseille Université, CNRS, LCE UMR7376, 13331 Marseille, France \\ (E-mail: tarek.manasfi@univ-amu.fr; brice.temime-roussel@univ-amu.fr; bruno.coulomb@univ-amu.fr; \\ laurent.vassalo@univ-amu.fr; jean-luc.boudenne@univ-amu.fr) \\ *Corresponding Author: Address: Aix Marseille Université, 3 Place Victor Hugo, Case 29, 13331 Marseille, France; \\ Telephone: +33 4 13551042; Email: tarek.manasfi@univ-amu.fr
}

\begin{abstract}
An undesirable consequence of disinfection is the formation of chemical contaminants known as disinfection byproducts (DBPs). Chronic exposure to DBPs has been linked to adverse health effects. The occurrence of DBPs in chlorinated pools filled with seawater (such as thalassotherapy pools and pools in spas) has received little attention so far. The present study evaluated the speciation and levels of disinfection byproducts in indoor swimming pools filled with seawater and treated with chlorine. Water and air samples were collected from three indoor swimming pools located in Southern France. Several classes of DBPs including trihalomethanes, haloacetic acids, haloacetonitriles, and trihaloacetaldehydes were analyzed in water. Halogenated volatile organic compounds were analyzed in air. Extractable organic halide (EOX) contents were determined using combustion micro-coulometry system. The speciation of DBPs identified in the three pools was predominantly brominated. The mean (arithmetic) concentration of bromoform, dibromoacetic acid, tribromoacetic acid, dibromoacetonitrile and bromal hydrate in the three pools were 79.2, 72.9, 59.9, 26.9 and $10.0 \mu \mathrm{g} / \mathrm{L}$, respectively. By weight, HAAs represented the most abundant chemical class followed by THMs. In air, bromoform was the most abundant THM occurring at a mean concentration of $133.2 \mu \mathrm{g} / \mathrm{m}^{3}$ in the three pools. The mean EOX level was $706 \mu \mathrm{gCl}^{-} / \mathrm{L}$ for the three pools. In average, the quantified DBPs accounted for only $14 \%$ of EOX, thus $86 \%$ of EOX remained unknown. Further research is warranted to identify the unknown DBPs.
\end{abstract}

\section{Keywords}

Disinfection byproducts; seawater swimming pools; brominated compounds; chlorination; total organic halide

\section{Introduction}

Disinfection is a critical process in which pathogenic microorganisms are eliminated from water. During this process, undesirable byproducts known as disinfection byproducts (DBPs) are formed because of reactions between disinfectants and organic compounds present in water. Swimming pool water constitutes a medium in which complex loads of organic compounds are brought into water by swimmers (Lakind et al., 2010). Discharges of saliva, sweat, hair particles, or personal care products are sources of organic compounds that react with disinfectants and ultimately lead to the formation of DBPs (Chowdhury et al., 2014b; Hansen et al., 2012; Kim et al., 2002; Teo et al., 2015). The occurrence of DBPs in swimming pools constitutes a health concern since 
exposure to these compounds has been linked to a range of adverse health effects (Hrudey, 2009; Villanueva et al., 2015). Chronic exposure to DBPs has been associated with an increased risk of bladder cancer (Villanueva et al., 2004). Some epidemiological studies have suggested an increased risk of asthma among professional swimmers and child swimmers (Font-Ribera et al., 2010; Weisel et al., 2009). Some studies have demonstrated that DBPs could induce adverse reproductive health outcomes (Klinefelter et al., 1995; Nieuwenhuijsen et al., 2000). Furthermore, extensive evidence exists about the genotoxicity and carcinogenicity of several DBPs (Richardson et al., 2007). Exposure to DBPs in swimming pools may take place via dermal absorption, inhalation, and ingestion (Zwiener et al., 2007a). Inhalation and dermal exposure have been considered to be the main routes of human exposure to DBPs in swimming pools, while ingestion from accidental water swallowing has been classified as a minor route (Xu and Weisel, 2005; Zwiener et al., 2007a). The occurrence of DBPs in swimming pools has been investigated in numerous studies (Chowdhury et al., 2014b). Among DBPs, trihalomethanes (THMs) and haloacetic acids (HAAs) have been studied extensively in swimming pools around the world (Aggazzotti and Predieri, 1986; Aggazzotti, G., Fantuzzi, G., Tartoni, P.L. and Predieri, 1990; Chu and Nieuwenhuijsen, 2002; Daiber et al., 2016; Dyck et al., 2011; Judd and Black, 2000; Kim et al., 2002; Manasfi et al., 2016; Parinet et al., 2012; Simard et al., 2013). Richardson et al., 2010 identified more than 100 DBPs and measured the concentrations of chloramines and THMs in chlorinated and brominated swimming pools. Recently, Daiber et al., (2016) evaluated the occurrence of DBPs and the associated mutagenicity of water in swimming pools and spas. However, the overwhelming majority of these studies investigated the levels and speciation of DBPs in chlorinated swimming pools filled with municipal (tap) water. Very little data has been documented regarding the speciation and levels of DBPs in chlorinated pools filled with seawater. In the latter, the high salt content particularly in bromide and the slightly basic $\mathrm{pH}(\sim 8)$ could affect the formation reactions of DBPs leading to DBP profiles and distributions distinct from those typically found in tap water pools (Hansen et al., 2012; Hua et al., 2006; Le Roux et al., 2012). Since the early 1900s, the use of seawater in swimming pools has been widely practiced in thalassotherapy centers in Europe for presumed health benefits (Parinet et al., 2012). Furthermore, seawater pools can now be found in water parks around the Mediterranean and on cruise ships and ferries (World Health Organization, 2006). Seawater pools are also found in hotels and spas over the world, especially those offering wellness programs (Smith and Puczko, 2009). In France, there are around fifty thalassotherapy centers distributed along the coasts (Charlier and Chaineux, 2009). According to some estimates, French thalassotherapy centers welcome more than one million users annually (Schwartz, 2005). For adverse health outcome considerations, the formation of DBPs in seawater is an issue of concern since the few studies conducted in seawater pool setting showed a predominance of brominated DBPs. Several studies have provided evidence regarding the far higher toxicities of brominated DBPs compared to their chlorinated analogues (Jeong et al., 2015; Manasfi et al., 2017; Plewa et al., 2010; Richardson et al., 2007; Yang et al., 2014). In previous investigations, Parinet et al. (2012) studied the levels of two chemical classes of DBPs namely trihalomethanes (THMs) and haloacetic acids (HAAs) in chlorinated seawater pools. In a recent study, Manasfi et al. (2016) reported the levels of several classes of DBPs including THMs, HAAs, haloacetonitriles (HANs), and trihaloacetaldehydes (THAs) in seawater pools in Southeastern France. However, no data has been provided so far regarding the occurrence of DBPs in the air of seawater pools and the organic halide contents of water in these pools. The present study was conducted in order to investigate the speciation and levels of DBPs in the air and water of indoor seawater pools in Southern France. The study also aimed at determining the extractable organic halide (EOX) contents of these pools and evaluating 
the contribution of the traditionally measured and some emerging DBP chemical classes to the EOX concentrations. Determining the occurrence of DBPs in air and water of seawater pools will help document data that is necessary for risk assessment studies.

\section{Materials and Methods}

\section{Study Site and Sample collection}

Three indoor swimming pools located in Southern France were included in the study. All the pools were filled using seawater and treated with chlorine. A detailed description of the studied pools including type of activity, pool volume, pool area, water filtration type, and average daily frequentation is presented in Table S1.

Table S1. Characteristics of the studied indoor chlorinated seawater pools

\begin{tabular}{llllllll}
\hline Pool & $\begin{array}{l}\text { Surface } \\
\left(\mathrm{m}^{2}\right)\end{array}$ & $\begin{array}{l}\text { Depth } \\
(\mathrm{m})\end{array}$ & $\begin{array}{l}\text { Volume } \\
\left(\mathrm{m}^{3}\right)\end{array}$ & $\begin{array}{l}\text { Type of } \\
\text { filtration }\end{array}$ & $\begin{array}{l}\text { Type of } \\
\text { use }\end{array}$ & $\begin{array}{l}\text { Age } \\
\text { Category }\end{array}$ & $\begin{array}{l}\text { Mean Daily } \\
\text { Frequentation }\end{array}$ \\
\hline $\mathrm{F}$ & 143 & 1.5 & 215 & Sand & $\begin{array}{l}\text { Swimming/ } \\
\text { relaxing }\end{array}$ & Adult & 40 \\
$\mathrm{H}$ & 91 & $0.8-2.2$ & 160 & Sand & $\begin{array}{l}\text { Swimming/ Adult } \\
\text { relaxing } \\
\text { Swimming/ Adult }\end{array}$ & 65 \\
$\mathrm{~J}$ & 24 & 1.3 & 32 & Sand & $\begin{array}{l}\text { Swimi } \\
\text { sport }\end{array}$ & & \\
\hline
\end{tabular}

*e.g. aerobic exercises in water

In all the pools, seawater was obtained from the Mediterranean and was sand filtered before filling the pools. The sampling campaign was conducted in spring 2016. Free residual chlorine and total chlorine were determined on-site during sampling. Other physicochemical parameters including temperature, $\mathrm{pH}$, and conductivity were also determined on-site using specific electrodes (WTW Multiline P4 multimeter, Weilheim, Germany). Samples were collected in triplicates for laboratory analysis. To determine total organic carbon (TOC), total nitrogen (TN), and bromide $\left(\mathrm{Br}^{-}\right)$levels, samples were collected in amber glass bottles $(1 \mathrm{~L})$ with PTFE-lined screw caps. In addition, samples were collected in $65-\mathrm{mL}$ vials with PTFE-lined screw caps for the analysis of DBPs and EOX in water. In these samples, ascorbic acid was added as a quenching agent in the vials before sampling, and the vials were filled without any remaining headspace to avoid any loss of volatile DBPs. All samples were transported at $4{ }^{\circ} \mathrm{C}$ and treated within $48 \mathrm{~h}$. For the analysis of DBPs in air, canisters (Entech) of 6-liter capacity were used to sample air in the indoor pools. Sampling was performed by filling canisters from the air above the water level $(1 \mathrm{~m})$ in less than one minute. A blank canister was obtained by collecting air samples from the ambient air outside swimming pool facilities.

\section{Chemicals}

Analytical standards including THM calibration mix, halogenated volatile mix (containing HANs), HAA esters calibration mix, 2,3-dibromopropionic acid solution, and chloral hydrate solution were purchased from Supelco (USA). Tribromoacetaldehyde (97\%) was purchased from Aldrich (United Kingdom) and was used to generate its hydrated form bromal hydrate $(\mathrm{BH})$ in 
ultrapure water (Millipore, resistivity $>18 \mathrm{M} \Omega \mathrm{cm}$ ). A standard stock solution of each compound was prepared in Methyl tert-butyl ether (MTBE, purity 99.8\%) which was purchased from Merck (Germany). L-ascorbic acid, crystalline, reagent grade was purchased from Sigma (China). Sulfuric acid, analytical grade reagent, was purchased from Fisher Scientific (UK).

\section{Water sample preparation}

For the analysis of EOX, THMs, HANs, THAs sample aliquots $(50 \mathrm{~mL})$ were first adjusted to a $\mathrm{pH}$ value ranging between 4.5 and 5.5 by adding sulfuric acid. Samples were then extracted by liquid-liquid extraction (LLE) by adding MTBE $(5 \mathrm{~mL})$ and shaking manually during 2 min. Then, the organic phase was separated. For the analysis of HAAs, U.S.EPA method 552.3 (Domino et al., 2003) was used with slight modifications. In brief, sample aliquots $(40 \mathrm{~mL})$ were acidified to a $\mathrm{pH}<1$ by adding concentrated sulfuric acid and were then extracted with MTBE (4 $\mathrm{mL}$ ). 2,3-dibromopropionic acid was added to the extracts as a surrogate. Subsequently, the resulting organic phase was transferred into $15 \mathrm{~mL}$ vials to which acidified methanol was added and placed in a water bath at $50{ }^{\circ} \mathrm{C}$ for $2 \mathrm{~h}$ to transform the HAAs into their methyl ester derivatives. After cooling, $4 \mathrm{~mL}$ of saturated sodium bicarbonate solution were added before collecting the organic phase containing the HAA esters in chromatographic vials.

\section{Analytical methods for water analysis}

Free residual chlorine and total chlorine were measured on-site by the colorimetric DPD method using a portable spectrophotometer (AQUALYTIC-AL 800, Germany). Bromide levels in water were measured using an ICS-3000 Dionex ion chromatography system, $30 \mathrm{mM} \mathrm{NaOH}$ eluent with a flow rate of $1.5 \mathrm{ml} / \mathrm{min}$ at $30{ }^{\circ} \mathrm{C}$. A Dionex IonPac AS11-HC $(4 \times 250 \mathrm{~mm})$ analytical column and a Dionex Ionpac AG11-HC $(4 \times 50 \mathrm{~mm})$ guard column were used (Thermo Scientific, USA). Total Organic Carbon (TOC) and Total Nitrogen (TN) were measured using high temperature catalytic oxidation technique (Multi N/C 2100, Analytik Jena, Germany). The pretreated sample was injected $(50 \mu \mathrm{l})$ into the furnace filled with a Pt preconditioned catalyst. The combustion was realized at $800{ }^{\circ} \mathrm{C}$ and the combustion products were carried by high purity oxygen (Linde Gas) allowing detection of $\mathrm{CO}_{2}$ by non-dispersive infrared (NDIR) and detection of NO by chemiluminescence (CLD). Organic extracts containing DBPs were analyzed using a gas chromatograph coupled to a ${ }^{63} \mathrm{Ni}$ electron-capture detector (GC-ECD model Clarus 580, Perkin Elmer, Norwalk, CT, USA). An Elite 5MS capillary column was used for the separation. Helium 5.0 was used as a carrier gas at $1 \mathrm{~mL} / \mathrm{min}$. Nitrogen was used as a make-up gas at 30 $\mathrm{mL} / \mathrm{min}$. For the analysis of THMs, HPs, HANs and HKs, the temperature program was as follows: initially $35^{\circ} \mathrm{C}$ increasing to $145^{\circ} \mathrm{C}$ at a rate of $10^{\circ} \mathrm{C} / \mathrm{min}$, then at a rate of $20^{\circ} \mathrm{C} / \mathrm{min}$ up to $225{ }^{\circ} \mathrm{C}$ and finally at $10{ }^{\circ} \mathrm{C} / \mathrm{min}$ to $260{ }^{\circ} \mathrm{C}$, held for $2 \mathrm{~min}$. For the analysis of HAAs, the temperature was initially set to $40{ }^{\circ} \mathrm{C}$, then increased to $75{ }^{\circ} \mathrm{C}$ at a rate of $15{ }^{\circ} \mathrm{C} / \mathrm{min}$, then increased to $100{ }^{\circ} \mathrm{C}$ at $5^{\circ} \mathrm{C} / \mathrm{min}$, and finally temperature reached $135^{\circ} \mathrm{C}$ at $10{ }^{\circ} \mathrm{C} / \mathrm{min}$ and held for $2 \mathrm{~min}$. External calibration was performed using a set of 7 standard solutions. The solutions were prepared by adding aliquots of the standard stock solution in reconstituted seawater and later conducting the same treatment as pool water samples. Reconstituted seawater was prepared according to ASTM International standard practice for the preparation of substitute ocean water (method D1141-98, 2013). Analysis of organic halides was performed using a combustion/microcoulometer system. Coulometric titration with silver ions was performed using organic halide analyzer (TOX-300, Mitsubishi, A1-Envirosciences, France). The analyzer was coupled to an automatic boat controller (ABC-210, Mitsubishi, A1-Envirosciences, France). An aliquot of 50 
$\mu \mathrm{L}$ of the MTBE extracts obtained using LLE was injected using an autosampler (ASC-250L, Mitsubishi, A1-Envirosciences, France) equipped with a syringe of $100-\mu \mathrm{L}$ capacity. Samples were introduced into the combustion tube under a flow of $\mathrm{O}_{2}$ and $\mathrm{Ar}$ adjusted at $200 \mathrm{~mL} / \mathrm{min}$. The combustion of the extracted organohalides was followed by pyrolysis at $900{ }^{\circ} \mathrm{C}$ resulting in the formation of hydrogen halides (HX) which were then determined with micro-coulometric titration. Calibration was performed by spiking reconstituted seawater with bromoform. Precision and recovery were determined by injecting $50 \mu \mathrm{L}$ of MTBE extracts obtained from seawater spiked with bromoform at $376 \mathrm{\mu gCl}^{-} / \mathrm{L}$. Average percent recovery was $91.5 \%$ and relative standard deviation was $4.4 \%$ based on 4 replicates of the $376 \mathrm{\mu gCl}^{-} / \mathrm{L}$ solution. Data processing was performed using the software TOX-300 (version 1.0.0, A1-Envirosciences, France). For quality control, reconstituted seawater was extracted and used as a blank to demonstrate absence of contamination from the high chloride concentrations typically present in seawater. Seawater and water reagent blanks were included with each sequence. Analysis of samples was conducted in triplicate. Limits of detection (DL) and the limits of quantification (QL) for the analyzed chemicals and parameters are presented in Table S2.

Table S2. Method detection limits (DL) and quantification limits (QL) for the analyzed chemicals/parameters

\begin{tabular}{lll}
\hline Chemical/Parameter (Unit) & DL & QL \\
\hline Chloroform $(\mu \mathrm{g} / \mathrm{L})$ & 0.8 & 2.4 \\
Bromodichloromethane $(\mu \mathrm{g} / \mathrm{L})$ & 0.3 & 0.9 \\
Dibromochloromethane $(\mu \mathrm{g} / \mathrm{L})$ & 0.2 & 0.6 \\
Bromoform $(\mu \mathrm{g} / \mathrm{L})$ & 0.2 & 0.6 \\
Dichloroacetonitrile $(\mathrm{DCAN})(\mu \mathrm{g} / \mathrm{L})$ & 0.2 & 0.6 \\
Trichloroacetonitrile $(\mathrm{TCAN})(\mu \mathrm{g} / \mathrm{L})$ & 0.3 & 1.2 \\
Bromochloroacetonitrile $(\mathrm{BCAN})(\mu \mathrm{g} / \mathrm{L})$ & 0.3 & 0.9 \\
Dibromoacetonitrile $(\mathrm{DBAN})(\mu \mathrm{g} / \mathrm{L})$ & 0.2 & 0.6 \\
Monochloroacetic acid $(\mathrm{MCAA})(\mu \mathrm{g} / \mathrm{L})$ & 1.2 & 3.4 \\
Monobromoacetic acid $(\mathrm{MBAA})(\mu \mathrm{g} / \mathrm{L})$ & 0.9 & 2.7 \\
Dichloroacetic acid $(\mathrm{DCAA})(\mu \mathrm{g} / \mathrm{L})$ & 0.7 & 2.1 \\
Trichloroacetic acid $(\mathrm{TCAA})(\mu \mathrm{g} / \mathrm{L})$ & 0.5 & 1.5 \\
Bromochloroacetic acid $(\mathrm{BCAA})(\mu \mathrm{g} / \mathrm{L})$ & 0.5 & 1.5 \\
Dibromoacetic acid $(\mathrm{DBAA})(\mu \mathrm{g} / \mathrm{L})$ & 0.4 & 1.2 \\
Bromodichloroacetic acid $(\mathrm{BDCAA})(\mu \mathrm{g} / \mathrm{L})$ & 0.6 & 1.8 \\
Chlorodibromoacetic acid $(\mathrm{CDBAA})(\mu \mathrm{g} / \mathrm{L})$ & 0.5 & 1.5
\end{tabular}


Chloral hydrate $(\mu \mathrm{g} / \mathrm{L})$

Bromal hydrate $(\mathrm{BH})(\mu \mathrm{g} / \mathrm{L})$

Free Residual Chlorine (mg/L)

Total Chlorine (mg/L)

Total Organic Carbon (TOC) (mg C/L)

\section{Analytical methods for air analysis}

Analysis of air samples collected in canisters was carried out with a proton-transfer-reaction time-of-flight mass spectrometry (PTR-ToF-MS 8000, Ionicon Analytik GmbH, Innsbruck, Austria) equipped with a switchable reagent ion module. $\mathrm{O}_{2}{ }^{+}$mode was used to investigate the presence of halogenated volatile organic compounds (VOCs). $\mathrm{O}_{2}{ }^{+}$can be used as reagent ion to increase the detection ability of the PTR-ToF-MS, since VOCs with proton affinities lower than water can then be ionisable. Mass spectra up to an $\mathrm{m} / \mathrm{z}$ ratio of 500 were recorded, with a resolution $\mathrm{m} / \Delta \mathrm{m}$ of 3500 . Parameters of the PTR-ToF-MS during the experiments were as follows: $\mathrm{T}_{\text {drift }}=50{ }^{\circ} \mathrm{C}, \mathrm{P}_{\text {drift }}=2.04 \mathrm{mbar}, \mathrm{E} / \mathrm{N}=95 \mathrm{Td}, \mathrm{U}_{\text {drift }}=400 \mathrm{~V} . \mathrm{U}_{\text {drift }}$ is the electric potential applied to the drift tube; $\mathrm{T}_{\text {drift }}$ and $\mathrm{P}_{\text {drift }}$ are the temperature and the pressure in the drift tube, respectively. $\mathrm{E}$ is the strength of the electrical field in $\mathrm{V} / \mathrm{cm}$ and $\mathrm{N}$ is the gas number density in $\mathrm{cm}^{3}$. The ratio E/N in Townsend (1 Townsend $\left.=10^{-27} \mathrm{~cm}^{2} / \mathrm{V}\right)$ is a defining characteristic of the drift tube. Data from PTR-ToF-MS were analyzed with the software Tofware (version 2.5.7, Tofwerk). The air concentrations were calculated using the following equation:

$\left[\mathrm{VOC}^{+}\right]=\left[\mathrm{O}_{2}^{+}\right]_{0} \cdot[\mathrm{VOC}] \cdot \mathrm{k} \cdot \mathrm{t}$

Where $\left[\mathrm{O}_{2}^{+}\right]_{0}$ and [VOC+ $]$ are the transmission corrected densities of the primary ion $\mathrm{O}_{2}{ }^{+}$and of the $\mathrm{VOC}^{+}$ions respectively, expressed in counts per second (cps). $\mathrm{k}$ is the reaction rate constant between the VOC and $\mathrm{O}_{2}^{+}\left(\mathrm{cm}^{3} / \mathrm{s}\right)$ and $\mathrm{t}$ is the residence time of the ions in the drift tube $(\mathrm{t}=100$ $\mu \mathrm{s})$. Concentrations were calculated based on $\mathrm{O}_{2}{ }^{+}$reaction collisional rate of $2.10^{-9} \mathrm{~cm}^{3} / \mathrm{s}$.

\section{Results and Discussion}

\section{Physicochemical parameters}

Physicochemical parameters including air temperature, water temperature, $\mathrm{pH}$, conductivity, TOC, TN, bromide content, levels of free residual chlorine, and total chlorine were determined. Table 1 presents the values of the physicochemical parameters measured in the studied pools. 
Table 1. Physicochemical parameters of the studied pools

\begin{tabular}{|c|c|c|c|c|c|c|c|c|c|}
\hline Pool & $\begin{array}{l}\text { Air } \\
\text { Temperature } \\
\left({ }^{\circ} \mathrm{C}\right)\end{array}$ & $\begin{array}{l}\text { Water } \\
\text { Temperature } \\
\left({ }^{\circ} \mathrm{C}\right)\end{array}$ & $\mathrm{pH}$ & $\begin{array}{l}\text { Conductivity } \\
\text { at } 25^{\circ} \mathrm{C} \\
(\mathrm{mS} / \mathrm{cm})\end{array}$ & $\begin{array}{l}{[\mathrm{Br}-]} \\
(\mathrm{mg} / \mathrm{L})\end{array}$ & $\begin{array}{l}\text { Free } \\
\text { Chlorine } \\
(\mathrm{mg} / \mathrm{L})\end{array}$ & $\begin{array}{l}\text { Total } \\
\text { chlorine } \\
(\mathrm{mg} / \mathrm{L})\end{array}$ & $\begin{array}{l}\text { TOC } \\
(\mathrm{mg} / \mathrm{L})\end{array}$ & $\begin{array}{l}\mathrm{TN} \\
(\mathrm{mg} / \mathrm{L})\end{array}$ \\
\hline$F$ & 22.7 & 32.2 & 8.5 & 75.0 & 88.5 & 1.6 & 1.75 & 2.7 & 1.4 \\
\hline $\mathrm{H}$ & 21.5 & 30.9 & 8.4 & 65.6 & 75.0 & 1.3 & 1.50 & 3.1 & 1.8 \\
\hline $\mathrm{J}$ & 24.2 & 33.1 & 8.3 & 73.2 & 78.3 & 1.0 & 1.10 & 3.9 & 2.3 \\
\hline
\end{tabular}

The measured $\mathrm{pH}$ values ranged between 8.3 and 8.5. These $\mathrm{pH}$ values do not conform to the French recommendations for swimming pools, according to which $\mathrm{pH}$ should be maintained between 6.9 and 7.7 for pools treated with chlorine. This recommendation has been established to avoid decrease in the disinfecting ability, which takes place at higher $\mathrm{pH}$ due to the formation of the less potent hypochlorite ions $\left(\mathrm{OCl}^{-}\right)$(ANSES, 2010). The latter recommendation targets swimming pools without considering the type of pool filling water and a recommendation regarding $\mathrm{pH}$ that is specific to seawater pools or pools disinfected with bromine does not exist so far. However, in chlorinated seawater pools bromine is the disinfectant that is formed from the reaction of chlorine with bromide present in seawater. Thus, equilibrium between $\mathrm{HOBr} / \mathrm{BrO}^{-}$ $(\mathrm{pKa}=8.63)$ should be considered instead of equilibrium between $\mathrm{HOCl} / \mathrm{ClO}^{-}(\mathrm{pKa}=7.54)$. In this way, the $\mathrm{pH}$ between $8.3-8.5$ should not compromise disinfection. Pool temperatures ranged from 30.9 to $33.1{ }^{\circ} \mathrm{C}$ and 21.5 to $24.2{ }^{\circ} \mathrm{C}$ in water and air, respectively. Bromide levels were relatively high ranging from 75.0 to $88.5 \mathrm{mg} / \mathrm{L}$. Typically, seawater contains around 65 $\mathrm{mg} / \mathrm{L}$ bromide (Magazinovic et al., 2004). Conductivity of water ranged from 65.6 to 73.2 $\mathrm{mS} / \mathrm{cm}$. This high conductivity is in agreement with the high salt content expected in seawater. However, the higher conductivity and bromide concentrations measured in the pools compared to those typically measured in seawater could be due to evaporation especially that waters of these pools were heated. TOC levels ranged between 2.7 and $3.9 \mathrm{mg} / \mathrm{L}$. Previously, heterogeneous TOC levels varying from as low as $1.5 \mathrm{mg} / \mathrm{L}$ to as high as $39.3 \mathrm{mg} / \mathrm{L}$ have been reported in swimming pools (Chu and Nieuwenhuijsen, 2002; Hang et al., 2016). In seawater pools, Parinet et al. (2012) reported levels ranging between 2.8 and $8.6 \mathrm{mg} / \mathrm{L}$. More recently, TOC levels reaching $11.88 \mathrm{mg} / \mathrm{L}$ were detected in seawater swimming pools in Southeastern France during summer period (Manasfi et al., 2016). This variability in TOC levels is related to characteristics of the filling water as well as to swimmers behavior and activities since the latter are main contributors to TOC observed in pools (Simard et al., 2013). The lower levels of TOC measured in this study compared to other studies could be related to lower frequentation rates in the investigated pools. In addition, the type of activity of pools was mainly soft which could reduce the discharge of sweat in comparison to other pools where swimmers' activities could be more vigorous. TN levels ranged between 1.4 and $2.3 \mathrm{mg} / \mathrm{L}$. Human body fluid discharges in swimming pools are believed to be a major source of nitrogen in swimming pools (Chowdhury et al., 2014b). Keuten et al. (2012) studied the release of anthropogenic pollutants in swimming pools and estimated that $\mathrm{TN}$ released per person is $46 \mathrm{mg}$ within the first minute of showering. During a 30-min exercise, it was estimated that TN release reaches $77.3 \mathrm{mg} / \mathrm{bather}$ (Keuten et al., 2014). Free residual chlorine levels ranged between 1.0 and $1.6 \mathrm{mg} / \mathrm{L}$. The latter level is slightly 
higher than the maximal level recommended in France for free residual chlorine (between 0.4 and $1.4 \mathrm{mg} / \mathrm{L})($ ANSES, 2010).

\section{Occurrence of DBPs}

Table 2 provides an overview of the concentrations of DBPs measured in water and air of the studied pools.

Table 2. Concentrations of the identified DBPs in the water (in $\mu \mathrm{g} / \mathrm{L}$ ) and air (in $\mu \mathrm{g} / \mathrm{m}^{3}$ ) of the three indoor seawater pools

\begin{tabular}{|c|c|c|c|c|c|}
\hline Chemical & Pool F & Pool H & Pool J & Mean & SD \\
\hline \multicolumn{6}{|l|}{ In Water $(\mu \mathrm{g} / \mathrm{L})$} \\
\hline Chloroform & N.D & N.D & N.D & - & - \\
\hline Bromodichloromethane & N.D & N.D & N.D & - & - \\
\hline Dibromochloromethane & 2.1 & 4.5 & 5.5 & 4.0 & 1.7 \\
\hline Bromoform & 49.7 & 101.3 & 86.5 & 79.2 & 26.6 \\
\hline TTHM & 51.8 & 105.8 & 92.0 & 83.2 & 28.1 \\
\hline MCAA & N.D & N.D & N.D & - & - \\
\hline MBAA & N.D & N.D & N.D & - & - \\
\hline DCAA & N.D & N.D & N.D & - & - \\
\hline TCAA & N.D & N.D & N.D & - & - \\
\hline BCAA & 3.4 & 6.2 & 8.7 & 6.1 & 2.7 \\
\hline DBAA & 30.5 & 84.4 & 103.7 & 72.9 & 37.9 \\
\hline BDCAA & 1.1 & 1.6 & 3.3 & 2.0 & 1.2 \\
\hline CDBAA & 4.5 & 10.1 & 15.5 & 10.0 & 5.5 \\
\hline TBAA & 28.5 & 67.8 & 83.4 & 59.9 & 28.3 \\
\hline HAA-9 & 68.0 & 170.1 & 214.6 & 150.9 & 75.2 \\
\hline $\mathrm{CH}$ & N.D & N.D & N.D & - & - \\
\hline $\mathrm{BH}$ & 8.5 & 9.2 & 12.4 & 10.0 & 2.1 \\
\hline DCAN & N.D & N.D & N.D & - & - \\
\hline BCAN & N.D & N.D & N.D & - & - \\
\hline DBAN & 18.3 & 28 & 34.5 & 26.9 & 8.2 \\
\hline \multicolumn{6}{|l|}{ In air $\left(\mu \mathrm{g} / \mathrm{m}^{3}\right)$} \\
\hline Chloroform & N.D & N.D & N.D & - & - \\
\hline Bromodichloromethane & N.D & N.D & N.D & - & - \\
\hline Bromoform & 240.1 & 137.7 & 21.7 & 133.2 & 109.3 \\
\hline Dibromochloromethane & 20.7 & 13.0 & 3.6 & 12.4 & 8.6 \\
\hline
\end{tabular}

TTHM: sum of four trihalomethane concentrations (or THM-4); MCA: monochloroacetic acid; MBAA monobromoacetic acid; DCAA: dichloroacetic acid; TCAA: trichloroacetic acid; BCAA: bromochloroacetic acid; DBAA: dibromoacetic acid; BDCAA: bromodichloroacetic acid; CDBAA: chlorodibromoacetic acid; TBAA: 
tribromoacetic acid; HAA-9: sum of the nine haloacetic acid concentrations; N.D: Not Determined, for compounds which were not detected or at detected at levels below quantification limits

\section{DBPs in pool water}

In all the pools, the speciation of the occurring DBPs was predominantly brominated (Table 2). This speciation is linked to the relatively high levels of bromide present in the filling seawater, since bromide ions react with the added chlorine resulting in the formation of bromine (Deborde and von Gunten, 2008). Consequently bromine reacts with organic compounds leading to the formation of brominated DBPs (Heeb et al., 2014; Hua et al., 2006). Bromine is even more potent than chlorine in halogenating organic compounds (Gallard et al., 2003). Brominated DBPs detected in the pools included HAAs, THMs, HANs and THAs. Figure 1 shows the distribution of THMs in water. Among THMs, bromoform was the most abundant compound with concentrations that ranged from 49.7 to $101.3 \mu \mathrm{g} / \mathrm{L}$. Dibromochloromethane was also detected at lower levels (ranged from 2.1 to $5.5 \mu \mathrm{g} / \mathrm{L}$ ). In average, TTHM level in the three pools was $83.2 \pm$ $28.1 \mu \mathrm{g} / \mathrm{L}$. Data reported in the literature about levels of TTHMs in seawater pools is limited. Beech et al. (1980) reported high levels of TTHM $(657 \pm 354 \mu \mathrm{g} / \mathrm{L})$ in seawater pools in USA. Recently, Parinet et al. (2012) reported an important variability in TTHM levels in seawater pools in France with levels ranging from as low as $32.2 \mu \mathrm{g} / \mathrm{L}$ to as high as $995.6 \mu \mathrm{g} / \mathrm{L}$. In a previous report, Manasfi et al. (2016) reported levels ranging from 50.4 to $91.8 \mu \mathrm{g} / \mathrm{L}$ in seawater pools during summer period. Unlike in seawater pools, the occurrence of THMs in swimming pools filled with tap water has been well documented (Chu and Nieuwenhuijsen, 2002; Fantuzzi et al., 2001; Guilherme and Rodriguez, 2014; Lourencetti et al., 2012; Richardson et al., 2010; Righi et al., 2014; Simard et al., 2013; Zwiener et al., 2007b). In these pools, chloroform has been determined as the predominant THM. Chu and Nieuwenhuijsen (2002) reported average concentration of $125.2 \mu \mathrm{g} / \mathrm{L}$ in 8 indoor swimming pools in England. Richardson et al. (2010) reported a TTHM average levels of $49.6 \mu \mathrm{g} / \mathrm{L}$ and $60.2 \mu \mathrm{g} / \mathrm{L}$ in chlorinated and brominated tap water pools in Spain, respectively. Simard et al. (2013) reported an average TTHM level of 64 $\mu \mathrm{g} / \mathrm{L}$ in indoor swimming pools in Canada. Figure 2 shows the distribution of HAAs in water. Among HAAs, dibromoacetic acid (DBAA) was the most abundant compound followed by tribromoacetic acid (TBAA).

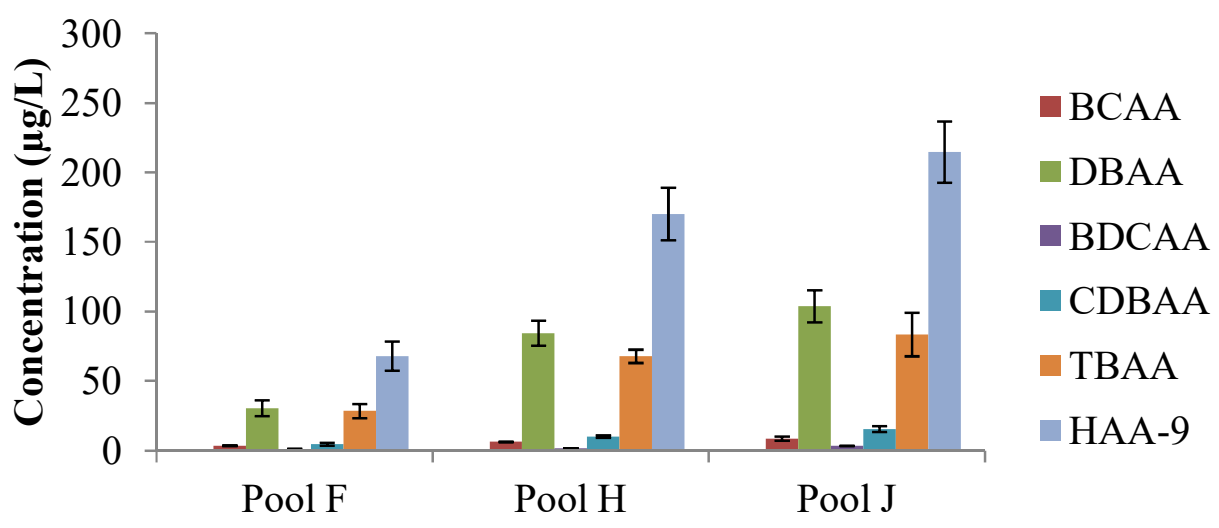

Figure 2. Distribution of the detected HAAs in the water of the studied pools. Error bars represent replicate standard deviation. 
These two compounds alone represented about $88 \%$ of the total HAA (HAA-9) content by weight.

Chlorodibromoacetic (CDBAA), bromochloroacetic acid (BCAA), and bromodichloroacetic acid (BDCAA) were also detected at levels far lower than those of DBAA and TBAA. In total, HAA9 ranged between 68.0 and $214.6 \mu \mathrm{g} / \mathrm{L}$ with an average concentration of $150.9 \pm 75.2 \mu \mathrm{g} / \mathrm{L}$. These levels tend to be situated in the lower range of HAA-9 levels that have been reported in swimming pools previously. Parinet et al. (2012) reported HAA-9 levels ranging between 84.01 and $2232.89 \mu \mathrm{g} / \mathrm{L}$ in seawater pools. Simard et al. (2013) reported an average level of $412.9 \mu \mathrm{g} / \mathrm{L}$ in indoor tap water pools. Tardif et al. (2016) reported levels ranging from 109.2 to $886.2 \mu \mathrm{g} / \mathrm{L}$ in indoor tap water pools. In tap water pools, dichloroacetic acid (DCAA) and trichloroacetic acid (TCAA acid), the chlorinated analogues of DBAA and TBAA respectively, represent the most abundant HAAs (Lee et al., 2010; Tardif et al., 2016).

In the present study, HAAs represented the most abundant chemical class (by weight) among the determined DBPs. The occurrence of HAAs at highest concentrations by weight has been observed for HAAs in tap water swimming pools also (Chowdhury et al., 2014b). This abundance of HAAs in chlorinated swimming pool water is distinct than that typically identified in drinking water. In the latter, THMs are the most abundant class of DBPs rather than HAAs. In swimming pools, the high abundance of HAAs is favored by anthropogenic organic inputs brought into water by swimmers (Kanan and Karanfil, 2011). In addition, HAAs exist in the ionic form at $\mathrm{pH}$ relevant to swimming pools and thus tend to accumulate in water without suffering from outgassing due to high volatility as in the case of THMs (Chowdhury et al., 2014a). Among HANs, dibromoacetonitrile (DBAN) was detected in the three pools at levels that ranged from 18.3 to $34.5 \mu \mathrm{g} / \mathrm{L}$ and an average concentration of $26.9 \pm 8.2 \mu \mathrm{g} / \mathrm{L}$. Interestingly, the highest concentration of HANs occurred in pool $J$ where TN was the highest $(2.3 \mathrm{mg} / \mathrm{L})$. The contribution of $\mathrm{N}$-containing compounds to the formation of HANs has been previously demonstrated (Shah and Mitch, 2012). Kim et al. (2002) observed that the presence of compounds such as urea and proteins of human origin promote the formation of HANs in chlorinated pool water. The N-containing amine precursors are present extensively in body fluids released by swimmers (Teo et al., 2015). Furthermore, the formation of HANs from precursors such as body fluid analogs was shown to increase in the presence of bromide ions (Hansen et al. 2011, Chowdhury et al., 2014b). Occurrence of HANs in seawater pools has been very scarcely documented. Levels comparable to those detected in this study were reported by Manasfi et al. (2016) in seawater pools where DBAN levels ranged between 14.0 and $28.6 \mu \mathrm{g} / \mathrm{L}$. Recently, Daiber et al. (2016) reported levels of DBAN ranging between 35.3 and $1102 \mu \mathrm{g} / \mathrm{L}$ in brominated pools and spas. HANs occurrence in tap water swimming pools has been investigated by fewer studies compared to the occurrence of THMs and HAAs (Chowdhury et al., 2014b). Lee et al. (2010) reported dichloroacetonitrile (DCAN) as the predominant HAN in tap water pools with an average level of $3.9 \mu \mathrm{g} / \mathrm{L}$. Hang et al. (2016) reported levels of DCAN varying from less than 0.5 up to $205.5 \mu \mathrm{g} / \mathrm{L}$ in chlorinated tap water swimming pools. Among THAs, bromal hydrate $(\mathrm{BH})$, which is the hydrated form of tribromoacetaldehyde, was detected in the three pools at levels that ranged from 8.5 to $12.4 \mu \mathrm{g} / \mathrm{L}$ with a mean concentration of $10.0 \pm 2.1 \mu \mathrm{g} / \mathrm{L}$. The occurrence of $\mathrm{BH}$ in seawater pools has been very poorly documented. However, recent evidence about its mutagenic and genotoxic potential warrants further investigations concerning the occurrence of this compound in swimming pools (Manasfi et al., 2017). In tap water pools, chloral hydrate, the chlorinated analogue of $\mathrm{BH}$, has been frequently detected. Lee et al. (2010) reported an average level of $10.2 \mu \mathrm{g} / \mathrm{L}$ in swimming pools in Korea. Daiber et al. (2016) reported levels as high as $556 \mu \mathrm{g} / \mathrm{L}$ in chlorinated public pools in USA. 


\section{DBPs in pool air}

Bromoform and dibromochloromethane were detected and quantified in the ambient air of the three pools. The main halogenated species detected were assigned their formulae based on the measured exact mass and the isotopic peak patterns: $\mathrm{CHBr}_{2}{ }^{+}(\mathrm{m} / \mathrm{z} 170.844)$, and $\mathrm{CHClBr}^{+}(\mathrm{m} / \mathrm{z}$ 126.894). Reactions between halogenated VOCs and $\mathrm{O}_{2}{ }^{+}$as reagent ion have been reported to proceed via a dissociative charge transfer reaction, generally resulting in the loss of a halogenated atom (Spanel and Smith, 1999). In the case of THM containing both bromine and chlorine atoms, the loss of a bromine atom is favoured (Mayhew et al., 2003). Accordingly, $\mathrm{CHBr}_{2}^{+}$and $\mathrm{CHBrCl}^{+}$represented the ions obtained from bromoform $\left(\mathrm{CHBr}_{3}\right)$ and dibromochloromethane $\left(\mathrm{CHBr}_{2} \mathrm{Cl}\right)$ after bromine loss, respectively. Other halogenated species namely $\mathrm{BrO}^{+}(\mathrm{m} / \mathrm{z}$ 94.913) and $\mathrm{BrCO}^{+}(\mathrm{m} / \mathrm{z}$ 106.913) were also detected but their origin has not been elucidated yet.

As shown in Table 2, bromoform was the predominant DBP in air in the three pools at concentrations ranging from 21.7 to $240.1 \mu \mathrm{g} / \mathrm{L}$ and a mean concentration of $133.2 \pm 109.3$ $\mu \mathrm{g} / \mathrm{m}^{3}$. Dibromochloromethane was detected at levels ranging between 3.6 and $20.7 \mu \mathrm{g} / \mathrm{m}^{3}$ with a mean concentration of $12.4 \pm 8.6 \mu \mathrm{g} / \mathrm{m}^{3}$. In total, TTHM level in air ranged between 25.3 and $260.8 \mu \mathrm{g} / \mathrm{m}^{3}$ with a mean concentration of $145.6 \pm 117.8 \mu \mathrm{g} / \mathrm{m}^{3}$.

Figure 3 shows the distribution of TTHM levels in the air and water of the pools. While water in pool $\mathrm{H}$ had two-fold higher TTHM concentration than in pool $\mathrm{F}(105.8$ and $51.8 \mu \mathrm{g} / \mathrm{L}$, respectively), air in pool $\mathrm{H}$ contained lower TTHM concentration than in pool F (150.7 and 260.8 $\mu \mathrm{g} / \mathrm{m}^{3}$, respectively).

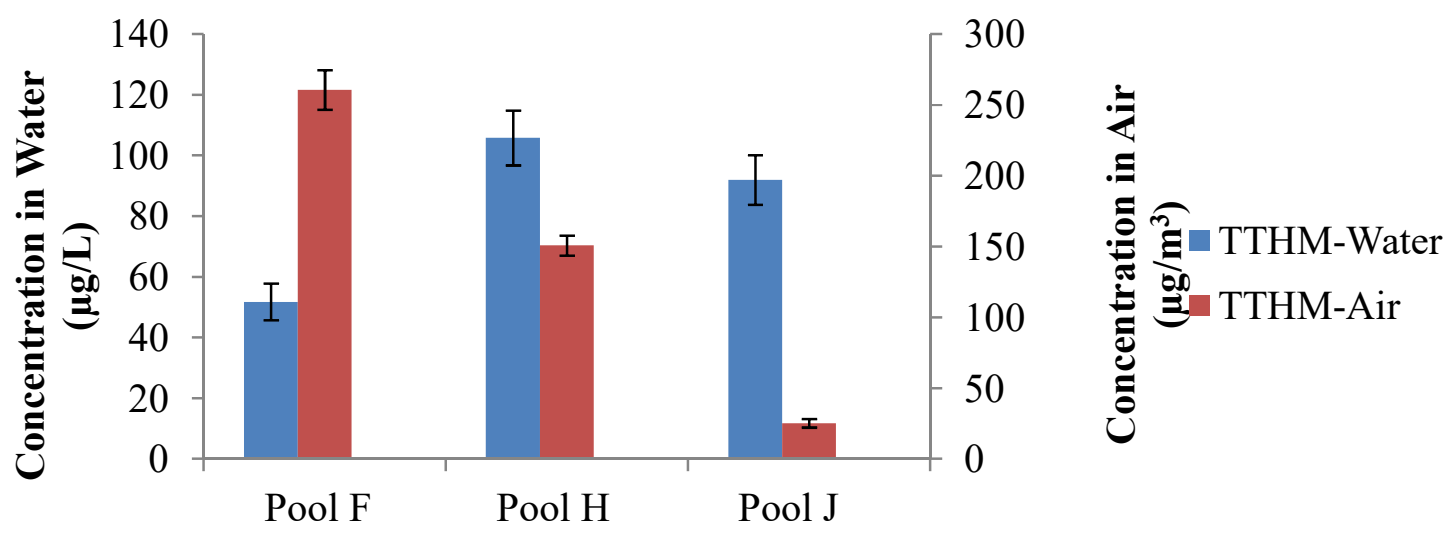

Figure 3. Distibution of total trihalomethanes (TTHM) in the air and water of the studied pools. Error bars represent replicate standard deviation

Furthermore, while pools $\mathrm{H}$ and $\mathrm{J}$ had comparable TTHM concentrations in water (105.8 and $92.0 \mu \mathrm{g} / \mathrm{L}$, respectively), they had considerably different TTHM concentrations in air (150.7 and $25.3 \mu \mathrm{g} / \mathrm{m}^{3}$, respectively). Previously, THM concentrations in pool water and air have not been strongly correlated (Aggazzotti et al., 1995). Several factors could affect the outgassing of volatile compounds into the air including water temperature, air temperature, concentration in water, intensity of air circulation (ventilation), and the turbulence in water caused by vigorous activity of pool users (Chowdhury et al., 2014b). In this study, the high TTHM level in the air in pool $\mathrm{F}$ seems related to poor ventilation in this facility (partially defective ventilation system as 
described by the pool operator). To our knowledge, this is the first paper reporting the levels of THMs in the ambient air of chlorinated indoor seawater pools. The air concentrations of bromoform reported here are comparable to levels reported for chloroform in the air of tap water pools. Chloroform concentrations ranging from 36 to $241 \mu \mathrm{g} / \mathrm{m}^{3}$ has been reported in the ambient air of indoor swimming pools in Germany (Lahl et al., 1981). Aggazzotti et al. (1995) reported chloroform levels ranging from 48.0 to $459.5 \mu \mathrm{g} / \mathrm{m}^{3}$ in indoor swimming pools in Italy. More recently, Richardson et al. (2010) reported mean TTHM levels of 72.1 and $89.5 \mu \mathrm{g} / \mathrm{m}^{3}$ in the air of chlorinated and brominated pools in Spain, respectively.

\section{Extractable Organic Halides (EOX) contents}

Table 3 shows the measured EOX contents in pool waters. EOX ranged between 510 and 920 $\mu \mathrm{gCl}^{-} / \mathrm{L}$ with a mean level of $706 \pm 205 \mu \mathrm{gCl}^{-} / \mathrm{L}$. The highest EOX was detected in pool $\mathrm{J}$ that also had the highest DBP content (by weight). The contribution of DBPs quantified in water to the total EOX ranged between 11 and $17 \%$ approximately.

Table 3. Extractable organic halides (EOX) levels and the percentage contribution of the identified chemical classes of DBPs to the measured EOX in pool waters

\begin{tabular}{llllll}
\hline & Pool F & Pool H & Pool J & Mean & SD \\
\hline EOX $(\mu \mathrm{gCl}-/ \mathrm{L})$ & 510 & 690 & 920 & 706 & 205 \\
Identified DBPs $($ by weight $)(\mu \mathrm{g} / \mathrm{L})$ & 146.6 & 313.1 & 353.5 & 271.1 & 109.7 \\
\% TTHM in EOX & 4.31 & 6.51 & 4.26 & 5.03 & 1.28 \\
\% HAA in EOX & 4.70 & 8.60 & 8.19 & 7.16 & 2.14 \\
\% HAN in EOX & 1.27 & 1.44 & 1.33 & 1.35 & 0.09 \\
\% THA in EOX & 0.59 & 0.47 & 0.48 & 0.52 & 0.07 \\
\% All identified DBPs in EOX & 10.87 & 17.02 & 14.26 & 14.05 & 3.08 \\
\hline
\end{tabular}

As a result, unknown halogenated species represented between 89 and $83 \%$ of the EOX contents of the pool waters. Figure 4 presents the mean contribution of the identified chemical classes of DBPs to the mean EOX in the three pools. HAAs represented the highest EOX fraction among the identified DBPs $(7.2 \%)$ followed by THMs (5.3\% of TOX). HANs (DBAN) and THAs (BH) represented $1.3 \%$ and $0.5 \%$ of EOX, respectively.

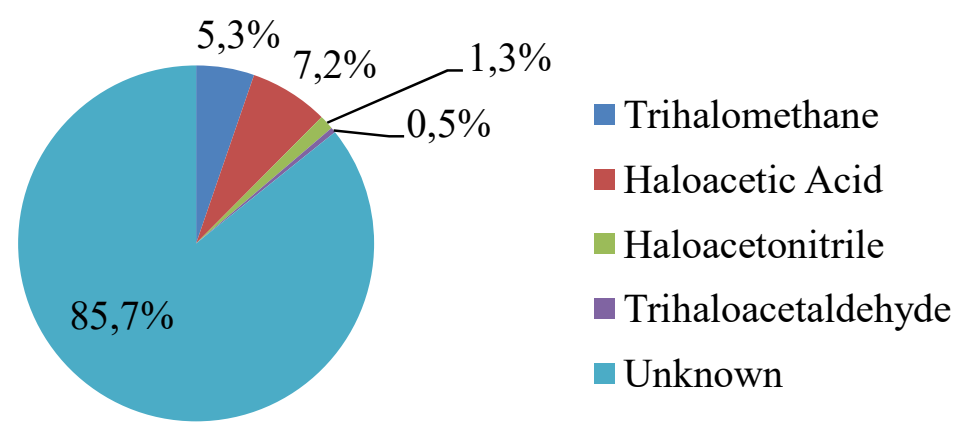

Figure 4. Mean contribution of the identified DBP chemical classes to the measured extractable organic halides (EOX) 
Consequently, an average $85.7 \%$ of EOX is still unaccounted for by the quantified DBPs in the indoor seawater pools. In drinking water, it has been estimated that around $70 \%$ of the EOX is still unknown (Richardson and Postigo, 2011). A higher unknown fraction of EOX in swimming pools is not surprising knowing that complex cocktails of organic precursors are introduced into pool waters (Lakind et al., 2010). The introduced organic loads react with disinfectants generating complex profiles of halogenated byproducts beyond those which are classically quantified (Daiber et al., 2016; Richardson et al., 2010). Precursors such as personal care products worn by swimmers can also react with disinfectants leading to the production of halogenated transformation products (Teo et al., 2015). Previous reports have shed the light on the implication of emerging precursors such as UV filters in the generation of DBPs in swimming pools (Manasfi et al., 2015; Santos et al., 2012; Zwiener et al., 2007a). Recently, halobenzoquinones were detected in swimming pool waters resulting from chlorination reactions of some personal care products (Wang et al., 2013).

\section{Conclusions}

This study shows that in chlorinated seawater pools the speciation of DBPs in the water and air is predominantly brominated. Bromoform, DBAA and TBAA, DBAN, and BH were the main THMs, HAAs, HANs and THAs detected in the three indoor pool waters, respectively. In the air, brominated THMs were detected with bromoform being the most abundant species. The occurrence of brominated DBPs at relatively high levels is of health concern since several investigations have demonstrated higher toxicities for brominated species (Jeong et al., 2015; Manasfi et al., 2017; Richardson et al., 2007; Yang et al., 2014). The quantified DBPs represented only a small fraction (an average of 14\%) of EOX content measured in the pools. Therefore, most of EOX (86\% fraction) was not accounted for by the quantified DBPs and remains unknown. These findings emphasize the need for further research to identify the halogenated DBPs with unknown nature and toxicity and for which users could be exposed to while swimming or in the context of an occupational exposure.

\section{References}

Aggazzotti, G., Fantuzzi, G., Righi, E., Predieri, G., 1995. Environmental and biological monitoring of chloroform in indoor swimming pools. J. Chromatogr. A 710, 181-190. doi:10.1016/0021-9673(95)00432-M

Aggazzotti, G., Predieri, G., 1986. Survey of volatile halogenated organics (VHO) in Italy. Levels of VHO in drinking waters, surface waters and swimming pools. Water Res. 20, 959-963. doi:10.1016/0043-1354(86)90036-9

Aggazzotti, G., Fantuzzi, G., Tartoni, P.L. and Predieri, G., 1990. Plasma Chloroform Concentrations in Swimmers Using Indoor Swimming Pools. Arch. Environ. Health 45, $175-179$.

ANSES (French Agency for Food, Environmental and Occupational Health and Safety), 2010. Health Risk Assessment in Swimming Pools. Part.1: public swimming pools. http://www.anses.fr/fr/system/files/EAUX2007sa0409Ra.pdf (last accessed on December $\left.18^{\text {th }}, 2016\right)$

ASTM D1141-98. Standard Practice for the Preparation of Substitute Ocean Water. ASTM 
International, USA (2008)

Beech, J. a., Diaz, R., Ordaz, C., Palomeque, B., 1980. Nitrates, chlorates and trihalomethanes in swimming pool water. Am. J. Public Health 70, 79-82. doi:10.2105/AJPH.70.1.79

Charlier, R.H., Chaineux, M.C.P., 2009. The healing Sea: a Sustainable coastal Ocean resource: thalassotherapy. Journal of Coastal Research 25, 838e856.

Chowdhury, S., Alhooshani, K., Karanfil, T., 2014a. Disinfection byproducts in swimming pool: Occurrences, implications and future needs. Water Res. 53, 68-109. doi:10.1016/j.watres.2014.01.017

Chowdhury, S., Al-hooshani, K., Karanfil, T., 2014b. Disinfection byproducts in swimming pool: Occurrences, implications and future needs. Water Res. doi:10.1016/j.watres.2014.01.017

Chu, H., Nieuwenhuijsen, M.J., 2002. Distribution and determinants of trihalomethane concentrations in indoor swimming pools. Occup. Environ. Med. 59, 243-247. doi:10.1136/oem.59.4.243

Daiber, E.J., DeMarini, D.M., Ravuri, S.A., Liberatore, H.K., Cuthbertson, A.A., ThompsonKlemish, A., Byer, J.D., Schmid, J.E., Afifi, M.Z., Blatchley, E.R., Richardson, S.D., 2016. Progressive Increase in Disinfection Byproducts and Mutagenicity from Source to Tap to Swimming Pool and Spa Water: Impact of Human Inputs. Environ. Sci. Technol. doi:10.1021/acs.est.6b00808

Deborde, M., von Gunten, U., 2008. Reactions of chlorine with inorganic and organic compounds during water treatment-Kinetics and mechanisms: A critical review. Water Res. 42, 13-51. doi:10.1016/j.watres.2007.07.025

Domino, M.M., Pepich, B. V., Munch, D.J., Fair, P.S., Xie, Y., 2003. METHOD 552.3 DETERMINATION OF HALOACETIC ACIDS AND DALAPON IN DRINKING WATER BY LIQUID-LIQUID MICROEXTRACTION, DERIVATIZATION, AND GAS CHROMATOGRAPHY WITH ELECTRON CAPTURE DETECTION. Environ. Prot. Agency, Cincinnati, $\mathrm{OH}$.

Dyck, R., Sadiq, R., Rodriguez, M.J., Simard, S., Tardif, R., 2011. Trihalomethane exposures in indoor swimming pools: A level III fugacity model. Water Res. 45, 5084-5098. doi:10.1016/j.watres.2011.07.005

Fantuzzi, G., Righi, E., Predieri, G., Ceppelli, G., Gobba, F., Aggazzotti, G., 2001. Occupational exposure to trihalomethanes in indoor swimming pools. Sci. Total Environ. 264, 257-265.

Font-Ribera, L., Kogevinas, M., Zock, J.P., Gómez, F.P., Barreiro, E., Nieuwenhuijsen, M.J., Fernandez, P., Lourencetti, C., Pérez-Olabarría, M., Bustamante, M., Marcos, R., Grimalt, J.O., Villanueva, C.M., 2010. Short-term changes in respiratory biomarkers after swimming in a chlorinated pool. Environ. Health Perspect. 118, 1538-1544. doi:10.1289/ehp.1001961

Gallard, H., Pellizzari, F., Croué, J.P., Legube, B., 2003. Rate constants of reactions of bromine with phenols in aqueous solution. Water Res. 37, 2883-2892. doi:10.1016/S00431354(03)00132-5 
Guilherme, S., Rodriguez, M.J., 2014. Occurrence of regulated and non-regulated disinfection by-products in small drinking water systems. Chemosphere 117, 425-32. doi:10.1016/j.chemosphere.2014.08.002

Hang, C., Zhang, B., Gong, T., Xian, Q., 2016. Occurrence and health risk assessment of halogenated disinfection byproducts in indoor swimming pool water. Sci. Total Environ. 543, 425-431. doi:10.1016/j.scitotenv.2015.11.055

Hansen, K.M.S., Willach, S., Antoniou, M.G., Mosbæk, H., Albrechtsen, H.-J., Andersen, H.R., 2011. Effect of selection of $\mathrm{pH}$ in swimming pools on formation of chlorination byproducts. In: Proceedings of Fourth International Conference Swimming Pool and Spa, Porto, Portugal

Hansen, K.M.S., Willach, S., Mosbæk, H., Andersen, H.R., 2012. Particles in swimming pool filters - Does $\mathrm{pH}$ determine the DBP formation? Chemosphere 87, 241-247. doi:10.1016/j.chemosphere.2012.01.003

Hansen, K.M.S., Willach, S., Antoniou, M.G., Mosbæk, H., Albrechtsen, H.-J., Andersen, H.R., 2012. Effect of $\mathrm{pH}$ on the formation of disinfection byproducts in swimming pool water - Is less THM better? Water Res. 46, 6399-6409. doi:10.1016/j.watres.2012.09.008

Heeb, M.B., Criquet, J., Zimmermann-Steffens, S.G., Von Gunten, U., 2014. Oxidative treatment of bromide-containing waters: Formation of bromine and its reactions with inorganic and organic compounds - A critical review. Water Res. 48, 15-42. doi:10.1016/j.watres.2013.08.030

Hrudey, S.E., 2009. Chlorination disinfection by-products, public health risk tradeoffs and me. Water Res. 43, 2057-2092. doi:10.1016/j.watres.2009.02.011

Hua, G., Reckhow, D.A., Kim, J., 2006. Effect of Bromide and Iodide Ions on the Formation and Speciation of Disinfection Byproducts during Chlorination. Environ. Sci. Technol. 40, 3050-3056. doi:10.1021/es0519278

Jeong, C.H., Postigo, C., Richardson, S.D., Simmons, J.E., Kimura, S.Y., Mariñas, B.J., Barcelo, D., Liang, P., Wagner, E.D., Plewa, M.J., 2015. Occurrence and Comparative Toxicity of Haloacetaldehyde Disinfection Byproducts in Drinking Water. Environ. Sci. Technol. 49, 13749-13759. doi:10.1021/es506358x

Judd, S.J., Black, S.H., 2000. Disinfection by-product formation in swimming pool waters: A simple mass balance. Water Res. 34, 1611-1619. doi:10.1016/S0043-1354(99)00316-4

Kanan, A., Karanfil, T., 2011. Formation of disinfection by-products in indoor swimming pool water: The contribution from filling water natural organic matter and swimmer body fluids. Water Res. 45, 926-932. doi:10.1016/j.watres.2010.09.031

Keuten, M.G. a, Schets, F.M., Schijven, J.F., Verberk, J.Q.J.C., van Dijk, J.C., 2012. Definition and quantification of initial anthropogenic pollutant release in swimming pools. Water Res. 46, 3682-3692. doi:10.1016/j.watres.2012.04.012

Keuten, M.G.A., Peters, M.C.F.M., Daanen, H.A.M., de Kreuk, M.K., Rietveld, L.C., van Dijk, 
J.C., 2014. Quantification of continual anthropogenic pollutants released in swimming pools. Water Res. 53, 259-70. doi:10.1016/j.watres.2014.01.027

Kim, H., Shim, J., Lee, S., 2002. Formation of disinfection by-products in chlorinated swimming pool water. Chemosphere 46, 123-130. doi:10.1016/S0045-6535(00)00581-6

Klinefelter, G.R., Suarez, J.D., Roberts, N.L., DeAngelo, A.B., 1995. Preliminary screening for the potential of drinking water disinfection byproducts to alter male reproduction. Reprod. Toxicol. 9, 571-8.

Lahl, U., Bätjer, K., Düszeln, J. V., Gabel, B., Stachel, B., Thiemann, W., 1981. Distribution and balance of volatile halogenated hydrocarbons in the water and air of covered swimming pools using chlorine for water disinfection. Water Res. 15, 803-814. doi:10.1016/00431354(81)90133-0

Lakind, J.S., Richardson, S.D., Blount, B.C., 2010. The good, the bad, and the volatile: Can we have both healthy pools and healthy people? Environ. Sci. Technol. 44, 3205-3210. doi:10.1021/es903241k

Lee, J., Jun, M.J., Lee, M.H., Lee, M.H., Eom, S.W., Zoh, K.D., 2010. Production of various disinfection byproducts in indoor swimming pool waters treated with different disinfection methods. Int. J. Hyg. Environ. Health 213, 465-474. doi:10.1016/j.ijheh.2010.09.005

Le Roux, J., Gallard, H., Croué, J.P., 2012. Formation of NDMA and halogenated DBPs by chloramination of tertiary amines: The influence of bromide ion. Environ. Sci. Technol. 46, 1581-1589. doi:10.1021/es203785s

Lourencetti, C., Grimalt, J.O., Marco, E., Fernandez, P., Font-Ribera, L., Villanueva, C.M., Kogevinas, M., 2012. Trihalomethanes in chlorine and bromine disinfected swimming pools: Air-water distributions and human exposure. Environ. Int. 45, 59-67. doi:10.1016/j.envint.2012.03.009

Magazinovic, R.S., Nicholson, B.C., Mulcahy, D.E., Davey, D.E., 2004. Bromide levels in natural waters: its relationship to levels of both chloride and total dissolved solids and the implications for water treatment. Chemosphere 57, 329-335.

doi:10.1016/j.chemosphere.2004.04.056Manasfi, T., De Méo, M., Coulomb, B., Di Giorgio, C., Boudenne, J.L., 2016. Identification of disinfection by-products in freshwater and seawater swimming pools and evaluation of genotoxicity. Environ. Int. 88, 94-102. doi:10.1016/j.envint.2015.12.028

Manasfi, T., Méo, M. De, Di, C., Coulomb, B., Boudenne, J., 2017. Assessing the genotoxicity of two commonly occurring byproducts of water disinfection : Chloral hydrate and bromal hydrate. Mutat. Res. - Genet. Toxicol. Environ. Mutagen. 813, 37-44. doi:10.1016/j.mrgentox.2016.11.009

Manasfi, T., Storck, V., Ravier, S., Demelas, C., Coulomb, B., Boudenne, J.-L., 2015. Degradation Products of Benzophenone-3 in Chlorinated Seawater Swimming Pools. Environ. Sci. Technol. 49, 9308-9316. doi:10.1021/acs.est.5b00841

Mayhew, C.A., Thomas, R., Watts, P., 2003. A selected ion flow tube investigation of the 
positive ion chemistry of a number of bromine containing fully and partially halogenated hydrocarbons. Int. J. Mass Spectrom. 223-224, 91-105. doi:10.1016/S1387-3806(02)007832

Nieuwenhuijsen, M.J., Toledano, M.B., Eaton, N.E., Fawell, J., Elliott, P., 2000. Chlorination disinfection byproducts in water and their association with adverse reproductive outcomes: a review. Occup. Environ. Med. 57, 73-85. doi:10.1136/oem.57.2.73

Parinet, J., Tabaries, S., Coulomb, B., Vassalo, L., Boudenne, J.-L., 2012. Exposure levels to brominated compounds in seawater swimming pools treated with chlorine. Water Res. 46, 828-836. doi:10.1016/j.watres.2011.11.060

Plewa, M.J., Simmons, J.E., Richardson, S.D., Wagner, E.D., 2010. Mammalian cell cytotoxicity and genotoxicity of the haloacetic acids, a major class of drinking water disinfection byproducts. Environ. Mol. Mutagen. 51, 871-8. doi:10.1002/em.20585

Richardson, S., Plewa, M., Wagner, E., Schoeny, R., Demarini, D., 2007. Occurrence, genotoxicity, and carcinogenicity of regulated and emerging disinfection by-products in drinking water: A review and roadmap for research. Mutat. Res. Mutat. Res. 636, 178-242. doi:10.1016/j.mrrev.2007.09.001

Richardson, S.D., DeMarini, D.M., Kogevinas, M., Fernandez, P., Marco, E., Lourencetti, C., Ballesté, C., Heederik, D., Meliefste, K., McKague, A.B., Marcos, R., Font-Ribera, L., Grimalt, J.O., Villanueva, C.M., 2010. What's in the Pool? A Comprehensive Identification of Disinfection By-products and Assessment of Mutagenicity of Chlorinated and Brominated Swimming Pool Water. Environ. Health Perspect. 118, 1523-1530. doi:10.1289/ehp.1001965

Richardson, S.D., Postigo, C., 2011. Drinking Water Disinfection By-products. Springer Berlin Heidelberg, pp. 93-137. doi:10.1007/698_2011_125

Righi, E., Fantuzzi, G., Predieri, G., Aggazzotti, G., 2014. Bromate, chlorite, chlorate, haloacetic acids, and trihalomethanes occurrence in indoor swimming pool waters in Italy. Microchem. J. 113, 23-29. doi:10.1016/j.microc.2013.11.007

Santos, a. J.M., Miranda, M.S., Esteves da Silva, J.C.G., 2012. The degradation products of UV filters in aqueous and chlorinated aqueous solutions. Water Res. 46, 3167-3176. doi:10.1016/j.watres.2012.03.057

Shah, A.D., Mitch, W.A., 2012. Halonitroalkanes, halonitriles, haloamides, and N-nitrosamines: A critical review of nitrogenous disinfection byproduct formation pathways. Environ. Sci. Technol. 46, 119-131. doi:10.1021/es203312s

Simard, S., Tardif, R., Rodriguez, M.J., 2013. Variability of chlorination by-product occurrence in water of indoor and outdoor swimming pools. Water Res. 47, 1763-1772. doi:10.1016/j.watres.2012.12.024

Smith, M., Puczko, L., 2009. Health and Wellness Tourism. Elsevier's Science \& Technology, Oxford, U.K. http://spss.en. softonic.com/ SPPS Statistics 17.0. 
Spanel, P., Smith, D., 1999. Selected ion flow tube studies of the reactions of H3O+, NO+, and $\mathrm{O} 2+$ with several aromatic and aliphatic hydrocarbons. Int. J. Mass Spectrom. 184, 175-181. doi:10.1016/S1387-3806(99)00103-7

Tardif, R., Catto, C., Haddad, S., Simard, S., Rodriguez, M., 2016. Assessment of air and water contamination by disinfection by-products at 41 indoor swimming pools. Environ. Res. 148, 411-420. doi:10.1016/j.envres.2016.04.011

Teo, T.L.L., Coleman, H.M., Khan, S.J., 2015. Chemical contaminants in swimming pools: Occurrence, implications and control. Environ. Int. doi:10.1016/j.envint.2014.11.012

Villanueva, C.M., Cantor, K.P., Cordier, S., Jaakkola, J.J.K., King, W.D., Lynch, C.F., Porru, S., Kogevinas, M., 2004. Disinfection byproducts and bladder cancer: a pooled analysis. Epidemiology 15, 357-67. doi:10.1097/01.ede.0000121380.02594.fc

Villanueva, C.M., Cordier, S., Font-Ribera, L., Salas, L.A., Levallois, P., 2015. Overview of Disinfection By-products and Associated Health Effects. Curr. Environ. Heal. reports 2, 107-115. doi:10.1007/s40572-014-0032-x

Wang, W., Qian, Y., Boyd, J.M., Wu, M., Hrudey, S.E., Li, X.F., 2013. Halobenzoquinones in swimming pool waters and their formation from personal care products. Environ. Sci. Technol. 47, 3275-3282. doi:10.1021/es304938x

Weisel, C.P., Richardson, S.D., Nemery, B., Aggazzotti, G., Baraldi, E., Blatchley, E.R., Blount, B.C., Carlsen, K.-H., Eggleston, P.A., Frimmel, F.H., Goodman, M., Gordon, G., Grinshpun, S.A., Heederik, D., Kogevinas, M., LaKind, J.S., Nieuwenhuijsen, M.J., Piper, F.C., Sattar, S.A., 2009. Childhood Asthma and Environmental Exposures at Swimming Pools: State of the Science and Research Recommendations. Environ. Health Perspect. 117, 500-507. doi:10.1289/ehp.11513

World Health Organization, 2006. Guidelines for Safe Recreational Water Environments, Volume 2 Swimming Pools and Similar Environments. World Health Organization, Geneva.

Xu, X., Weisel, C.P., 2005. Dermal uptake of chloroform and haloketones during bathing. J. Expo. Anal. Environ. Epidemiol. 15, 289-296. doi:10.1038/sj.jea.7500404

Yang, Y., Komaki, Y., Kimura, S.Y., Hu, H., Wagner, E.D., Marinas, B.J., Plewa, M.J., 2014. Toxic Impact of Bromide and Iodide on Drinking Water Disinfected with Chlorine or Chloramines. Environ. Sci. Technol. 48, 12362-12369.

Zwiener, C., Richardson, S.D., De Marini, D.M., Grummt, T., Glauner, T., Frimmel, F.H., 2007a. Drowning in Disinfection Byproducts? Assessing Swimming Pool Water. Environ. Sci. Technol. 41, 363-372. doi:10.1021/es062367v

Zwiener, C., Richardson, S.D., De Marini, D.M., Grummt, T., Glauner, T., Frimmel, F.H., $2007 b$. Drowning in disinfection byproducts? Assessing swimming pool water. Environ. Sci. Technol. 41, 363-372. doi:10.1021/es062367v 